contributions to botanical science stands to his name in the transactions of botanical societies and journals as well as in the Government publications of India and Mesopotamia. The practical aspect of his work in relation to the propagation of plants and the combating of plant-diseases in India, in Mesopotamia, and in Great Britain has been widely recognised.

\section{The Chinese Mitten Crab}

The Chinese mitten (or woolly-hand) crab, Eriocheir sinensis (see NATURE, June 9, p. 855), was transported to Germany from China in some unknown way and was first caught in the Aller (a tributary of the Weser) in 1912, but was not identified until 1923. It has spread widely in the river systems of Germany - the Elbe, Weser, Rhine and Oder. It is stated that about 700,000 of these crabs were caught in 1931 at Hamburg; the crab has in fact become a pest in some places. The adult crabs wander down the rivers at the beginning of the breeding season; pairing takes place in brackish water of the lower Elbe and Weser, but the crabs bearing eggs are found off the river estuaries in more saline water. In the interests of controlling the crab, Dr. W. Wolterstorff, of the Magdeburg Museum, has addressed questions to the Peking Society of Natural History. These and the answers are contained in the Bulletin of the Society, vol. 8, Part 3, March 1934. Dr. Wolterstorff refers to a report that the crabs were cleared out of the lower Liang Ho River about twenty years ago with nets, as they destroyed the fish, and asks if this was successful. $\mathrm{He}$ directs attention to the statement of Prof. Lu-fong of Tientsin that the Chinese consider the crabs holy and hence the crabs caught are not eaten but burnt, and points out that this is at variance with the statement of Marquard that the crab is a popular item of food in China. In reply to the questions, Y. T. Mao, of the Department of Biology, Yenching University, states that Eriocheir sinensis is one of the edible crabs commonly found along the coastal provinces of China and that the Chinese do not consider the crab holy. He adds that according to his observation it is not necessary for the crab to lay its eggs in salt water and that he has not heard that the crabs had to be cleared out from a river at Tientsin, nor has he heard of any river in China inhabited by such a large number of crabs as were stated to occur in the Elbe.

\section{Will the Chinese Mitten Crab Invade British Waters?}

The Ministry of Agriculture and Fisheries has issued a notice (Fisheries Notice, No. 22, June 1934) on this crab, pointing out that it "would in no wise be a welcome addition to the British fauna". During its migrations, particularly upstream, the crab tunnels into river banks and the wash of water in these burrows is liable to cause subsidence and hence serious damage to the banks. Further, the erab is varacious; it clears bait from lines and eats the fish taken thereon, and bites through nets and lines. The note suggests that a careful watch should be kept for this crab, especially on the east coast of Great
Britain; its destruction at all possible times might at least assist in restricting the numbers of this unwanted invader.

\section{Science and Social Problems}

IN a lecture on "The Man of Science and the Science of Man" delivered at the University of Liverpool on December 7, a copy of which reached us recently, Prof. J. L. Myres discusses the responsibility of science for social disorder. Much of the current confusion of thought in this matter he attributes to the common failure to distinguish discovery from invention, and, more dangerous still, the engineer or inventor from employers or exploiters who require an immediate solution of a particular practical problem in applied science for their own purpose. The man of science has an individual moral responsibility for the full use of his specific powers in investigating Nature and rationalising the world around him, and the growth of personal responsibilities, with the concurrent graver risks of personal abuse, provides some of our most serious social and international problems. One of the problems to which thought has not yet been adequately applied in this way is the problem of leisure, which is one with that of unemployment or disemployment through the growth of rationalisation or mechanisation of industry. For this our system of education, and particularly the high degree of specialisation in the training of students of science, are largely to blame and Prof. Myres enters an eloquent plea for expositors of science who are competent to impart to the general community something of the spirit and methods of science, so as to afford them an adequate general scientific background for the life they lead in this highly technical age.

Prof. Myres deals also a hard blow at the slovenliness of the scientific worker in his written communications whether for the specialist or a wider public, particularly his neglect to use current linguistic coin, acceptable at its face value of words or sense. These points in a valuable address may easily be overlooked by the scientific worker in his interest in the subsequent discussion of the clash of cultures in modern life and the way in which a science of man could be of service under modern conditions. A field of scientific research is here visualised, the results of which are potentially applicable to a wide range of everyday problems. There is required, too, the capacity to see life as a whole and not as a series of independent units. The latter tendency, no less than excessive specialisation, are major obstacles to the noble conception of citizenship for which Prof. Myres pleads, and which demands the exercise of freedom in speech, in thought and in life.

\section{National Art Gallery and Museum for New Zealand}

AT the ceremonial laying of the foundation stone of a National Art Gallery and Dominion Museum for New Zealand, at Wellington, on April 14, Lord Bledisloe, Grovernor-General of New Zealand, gave 
an inspiring address on the proper functions of such an institution. This has just been published in pamphlet form with the title "The Proper Function and Scope of a National Art Gallery and Museum". "A public museum . . . should not be a mausoleum of dead specimens, the resort only of monastic specialists or interested collectors, but a vitalising power-house radiating currents of intellectual energy and calling forth latent genius in all classes of the community". The difficulty is to know how best to do it. Lord Bledisloe suggests many possibilities : popular exhibits, the encouragement of school children, travelling collections to country districts, special exhibits relating to sanitation, hygiene, child-welfare or town-planning, a comprehensive department illustrative of British seafaring life from the earliest times, and so on. $\mathrm{He}$ summarises with insight the values of an orderly ethnographic collection-the scientific study of early civilisations, the promotion of a more sympathetic understanding of subject races, the provision of useful equipment to prospective Colonial administrators and pioneers, and the stimulation of trade by suggesting new ideas both to importers and exporters. On the museum side and on the art gallery side he warns curators and administrators over and over again against the danger of accepting gifts too readily, and of accepting gifts with conditions. He sees in the foundation of the new institute a landmark in the definite and vigorous intellectual and spiritual progress of all classes and both races of people in the Dominion.

WhILE in New Zealand Lord Bledisloe was laying emphasis upon the educative aspects of museums, at the Toronto Meeting of the American Association of Museums, on May 31, Prof. John R. Dymond, director of the Royal Ontario Museum of Zoology, sounded a warning note about the danger of too much educational policy (Science Service, Washington, D.C.). Education is one of the important functions of a museum, but it is not the only one, or the primary one. The peculiar work for which museums exist is to collect and preserve the irreplaceable materials needed for the advancement of knowledge. Should too great a proportion of time or energy or income be spent on educational activities, the real work of the museum will suffer. There are other agencies in every State devoted to educational work, but there is nothing to replace the museum if it halts in its labour of making and conserving collections. But the problem is not quite so simple as it looks-there are things that are not worth the labour and expense of collecting and preserving, and who is to draw the line between judicious collecting and aimless, useless amassing ? Perhaps the educational aspect is one of the soundest criteria.

\section{The Psychic Thumb Print Controversy}

IN Bulletin 22 of the Boston Society for Psychic Research, published in April 1934, is printed the reply to Mr. Thorogood's lengthy report on the alleged psychic thumb prints produced by the American medium 'Margery', which document was issued as vol. 22 of the Proceedings of the American Society for Psychical Research and which was reviewed in NATURE of April 14, p. 550. The controversy revolves around the report of the discovery that both the right and left thumb prints of 'Walter' (the medium's control) are in reality identical with those of her dentist now living in Boston. These charges were examined by the officials of the American Society for Psychical Research, who came to the conclusion that they were without foundation, although it was admitted that in the case of one of the thumb prints the resemblance was close. Counter charges of bad faith, falsification of material evidence and sinister motives were made, and it was alleged that certain of the wax prints obtained exhibit clear signs of alteration. In the present Bulletin these statements are considered, and further counter charges are made against the officers of the American Society for Psychical Research, including the suggestion that counterfeit waxes have been introduced and dates forged. In a well-balanced review of Mr. Thorogood's book, Dr. Harold Cummins examines the theory that the sets of prints are not identical, but finds himself unable to accept the claim. Moreover, he severely criticises certain photomicrographs printed by $\mathbf{M r}$. Thorogood inasmuch as in his opinion they are not strictly comparable.

\section{New 24-Cylinder Aero Engine}

As air-cooled 24-cylinder aero engine, the NapierDagger, has just completed its 100-hour Air Ministry type test. It has already been flown for more than sixty hours in a Hawker Hart day bomber aeroplane, and took part in this year's R.A.F. display on June 30 . The 24 cylinders are arranged in four blocks of six. Two blocks are set above and two below the crankcase, giving the engine the form of a letter $\mathrm{H}$ viewed from the front. This arrangement makes for compactness, especially in frontal area, which is about equal to that of a modern water-cooled engine of similar output. Thus the air-cooled engine gains to the extent of the head resistance of the radiators or such devices as are necessary for cooling the liquid in the other. Each pair of upper and lower cylinder blocks has a separate crank-shaft which transmits the power through gearing to the airscrew shaft. The reduction in this gearing allows the very high engine speed of 4,000 revolutions per minute, while the airscrew travels at such lower speeds as its efficiency demands. One of the most interesting features in the engine is the use of hydraulic impulses to operate the valve gear. This removes the need of rocker arms and also gives a quieter engine. The engine is supercharged to develop its maximum power of $705 \mathrm{~h} . \mathrm{p}$. at a height of $12,000 \mathrm{ft}$., and, at a cruising rate of 3,500 revolutions a minute, it yields 630 h.p. These are with standard fuels; much bigger outputs with 'doped' fuel and higher compression ratios are anticipated. A smaller version of this engine has been flying for some time. This has only 16 cylinders arranged in banks of four. It was known originally as the $H$ engine and is now named the Rapier. The bigger engine makes the type fit for use in military aircraft. 